\title{
Fundy Model Forest: Partners in sustainable forest management
}

\author{
by David A. MacLean ${ }^{1}$, Peter Etheridge ${ }^{2}$, Joe Pelham ${ }^{3}$ and Walter Emrich ${ }^{4}$
}

Scenario planning was used to develop a consensus-based, multistakeholder management planning process for a 114000 ha land base in New Brunswick, Canada. This is part of the Fundy Model Forest, which involves four major landowner groups, along with 26 other Partnership organizations. Public consultation and Partnership input were used to define 25 scenarios, determining effects of alternative means of riparian strip management, road construction, vegetation and insect control, harvesting, maintenance of biodiversity, and plantation establishment. The Woodstock forest modelling software was used to determine effects of each scenario on timber supply, forest structure, measures of biodiversity and ecological integrity, areas of mature forest, and wildlife habitat. In a series of workshops, the Partners were successful in reaching consensus on a Fundy Model Forest "preferred" management scenario, which was conveyed to the land managers for implementation. Development of the management planning process and the use of scenario planning procedures in the Fundy Model Forest are described.

Key words: scenario planning, sustainable forest management, Fundy Model Forest, timber supply, biodiversity
La planification par scénario a été utilisée pour élaborer un processus de planification de l'aménagement établi par consensus entre plusieurs intervenants pour un territoire de 114000 ha situé au Nouveau-Brunswick, Canada. Il s'agit d'un élément de la Forêt modèle de Fundy qui regroupe quatres groupes principaux de propriétaires, ainsi que 26 autres organismes partenaires. La consultation publique et les intrants des partenaires ont été utilisés pour établir 25 scénarios, déterminer les effets des mesures alternatives d'aménagement des bandes riveraines, de construction de chemin, de contrôle de la végétation et des insectes, de récolte, de maintien de la biodiversité, et d'établissement de plantation. Le logiciel de modélisation forestière Woodstock a été utilisé pour déterminer les effets de chacun des scénario sur les stocks de bois, la structure forestière, les mesures de biodiversité et d'intégrité écologique, les zones de forêt mature, et les habitats fauniques. Lors d'une série d'ateliers, les Partenaires ont réussi à atteindre un consensus autour d'un scénario d'aménagement "préféré" de la Forêt modèle de Fundy, qui a été transmis aux gestionnaires du territoire pour fin d'implantation. L'élaboration du processus de planification de l'aménagement et l'utilisation des procédures de planification par scénario pour la Forêt modèle de Fundy sont décrits.

Mots-clés: planification par scénario, aménagement forestier durable, forêt modèle de Fundy, approvisionnement en bois, biodiversité

\section{Introduction}

The degree of public participation in forest management has been steadily increasing over the past two decades in Canada. This increase is evident to the extent that many of the major issues facing foresters and scientists regarding how our forests are managed are largely influenced by socio-economic factors rather than by administrative and technical aspects of forest management. The Model Forest program was initiated in Canada in 1992 by Natural Resources Canada to address this situation, as well as to accelerate the rate at which scientific knowledge is developed and applied on the ground in forest management (Brand et al. 1996). The Model Forest program also allowed for the development of a structure for greater public involvement in forestry issues.

The Model Forest program is sponsored by the financial and in-kind contributions of Natural Resources Canada, Canadian Forest Service and many Partners. There are presently 11 Model Forests in Canada, representing all major forest regions in the country, and each representing a somewhat different socio-

\footnotetext{
${ }^{1}$ Chair, Fundy Model Forest Management Planning Committee; Natural Resources Canada, Canadian Forest Service, Atlantic Forestry Centre, P.O. Box 4000, Fredericton, NB E3B 5P7.

${ }^{2}$ General Manager, Fundy Model Forest, 181 Aiton Road, Sussex East, NB E4G 2V5.

${ }^{3}$ Formerly Database Manager, Fundy Model Forest; present address N.B. Department of Natural Resources and Energy, Hampton, NB.

${ }^{4}$ Planning Forester, J.D. Irving, Limited, 300 Union St., Saint John, NB E2L 4M3.
}

economic situation. The Canadian Forest Service has also initiated and developed associations with international Model Forests in Mexico, Russia, and the United States, and there is a growing level of awareness and interest by other countries as well. The network is expected to grow in the future.

The Fundy Model Forest (FMF) is a 420 000-ha working forest located in southeastern New Brunswick (Fig. 1). It is representative of the Acadian Forest Region. The land base has a diverse ownership comprised of $63 \%$ private woodlots, $15 \%$ Crown (publicly owned) land, 17\% J.D. Irving, Limited industrial freehold land, and 5\% Fundy National Park (Fig. 2). The FMF includes 30 Partnership organizations, representing land tenure groups, research agencies, municipalities, educational institutions, environmental organizations, and natural resource professional organizations (Table 1).

The issues that the FMF is addressing include development and implementation of a sustainable management planning process; biodiversity, water and soil conservation issues; ecosystem function, wood supply, multiple ownership issues, management of critical/sensitive areas, wildlife use and protection issues; education and recreation, and eco-tourism related issues. These areas are addressed by technical committees made up of scientists and experts in that particular discipline along with user groups and other stakeholders who are interested in how that particular forest value is managed.

The FMF Partnership that has evolved is based upon a $\mathrm{col}$ laborative stewardship approach, with a vision to balancing the local needs with regional and national concerns for conservation and sustainability within the forest sector. The 


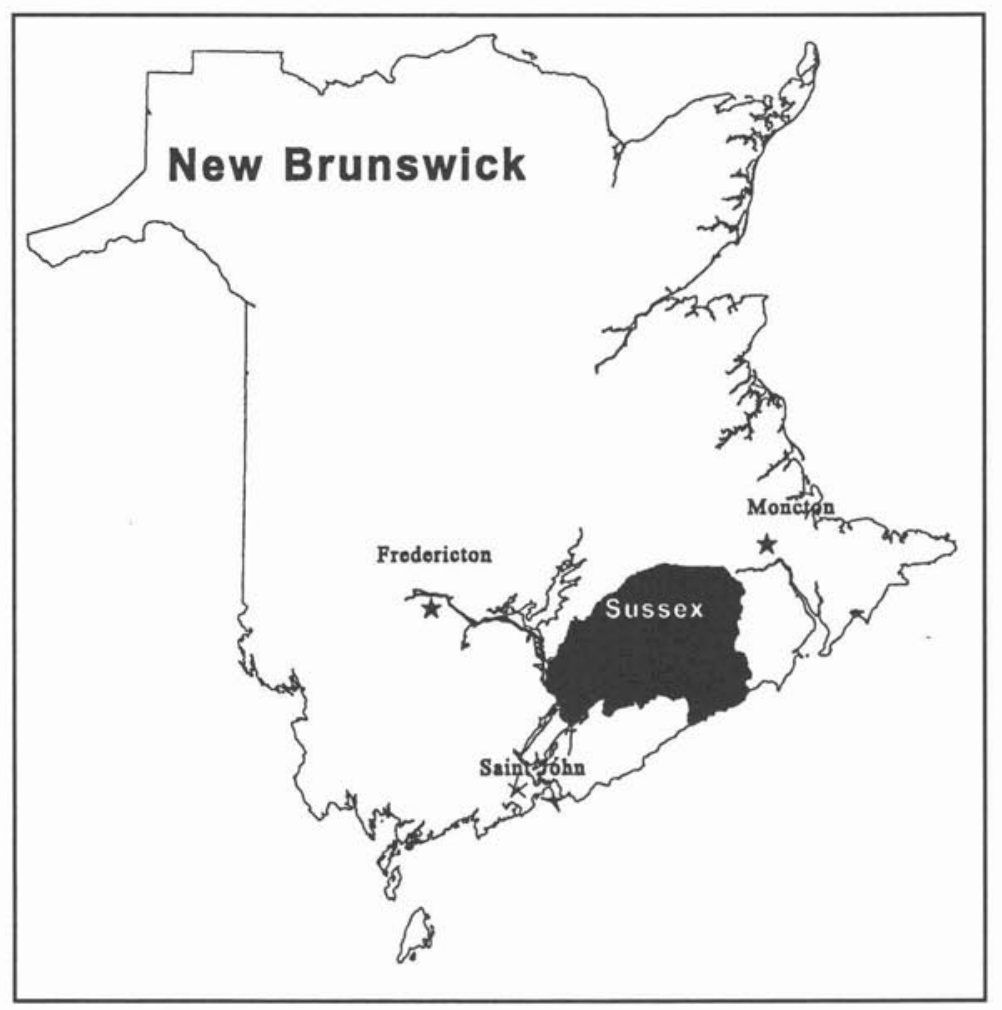

Fig. 1. Location of the Fundy Model Forest in southern New Brunswick.

FMF provides a demonstration for the Maritimes region of Canada, of people working together to solve local forest sustainability issues, in terms of socio-economic and ecological concerns to meet the changing needs of the population.

The FMF Partnership has gone through a formative process by which a certain level of trust and empowerment has been achieved. Partners have a sense that they can influence the management planning process across the multiple ownership land base and bring sustainability issues to the forefront. This process does not have a definitive ending point, rather, it is an evolving process and continues to be built upon as the Partners' awareness increases and issues become more clearly defined. The FMF has been successful in creating a strong dynamic partnership that functions with a true consensus decision making process (Gardner Pinfold 1996). As noted by Dr. Louis LaPierre, Chair of the FMF, in the 1995-96 Annual Report: "We have not realized all of our initial goals and objectives, however, we have developed a framework which allows us to debate contested issues in an atmosphere of trust and good will." The Model Forests are but one forum by which forest management interests in Canada are striving to further develop the concept of sustainable forest management.

In this paper, we will describe the sustainable forest management planning process that was begun in the first phase of the Fundy Model Forest (1992-1997) and which is continuing to evolve in the second phase of the program (1997-2002). This planning process has been implemented by each of the four landowner groups of FMF.

\section{The FMF Approach to Sustainable Forest Management}

A management plan is a geographically explicit treatment schedule designed to achieve the objective set for each resource value of interest. The management plan must specify what treatments are to be implemented, in what amounts, where and when. The FMF Management Planning Loop (Fig. 3) outlines the various steps in the process leading to revision, modification and enhancement. This defines our approach to adaptive forest management, in the sense that the Partnership recognizes that there are many knowledge gaps related to specific forest values that need to be addressed through further inventory, monitoring, and research. As more definitive information becomes available, it will be considered in the development, enhancement or modification of various forest value projections and treatment prescriptions. Many organizations are involved in the development of sustainable forest management planning processes, but one of the key strengths of the FMF approach has been the degree of public participation and representation of many diverse interests in the planning process.

There are three general steps in making a management plan (MacLean 1998):

1. Establishing objectives for all resource values of interest to the FMF Partnership - e.g., biodiversity values, preservation of critical areas, wood supply, soil, water quality, recreation, wildlife, etc.

2. Designing an acceptable management strategy. The future state of specific forest resource values (e.g., mature coniferous habitat, or $\mathrm{m}^{3}$ of timber supply) should be projected temporally for every class of stand in the forest, as a function of proposed management actions.

3. Assessing forest performance indicators. Forest performance indicators must be forecast during plan preparation, as well as monitored through the implementation phase to determine how the management strategy has affected the identified resources values and objectives. The effectiveness of the 


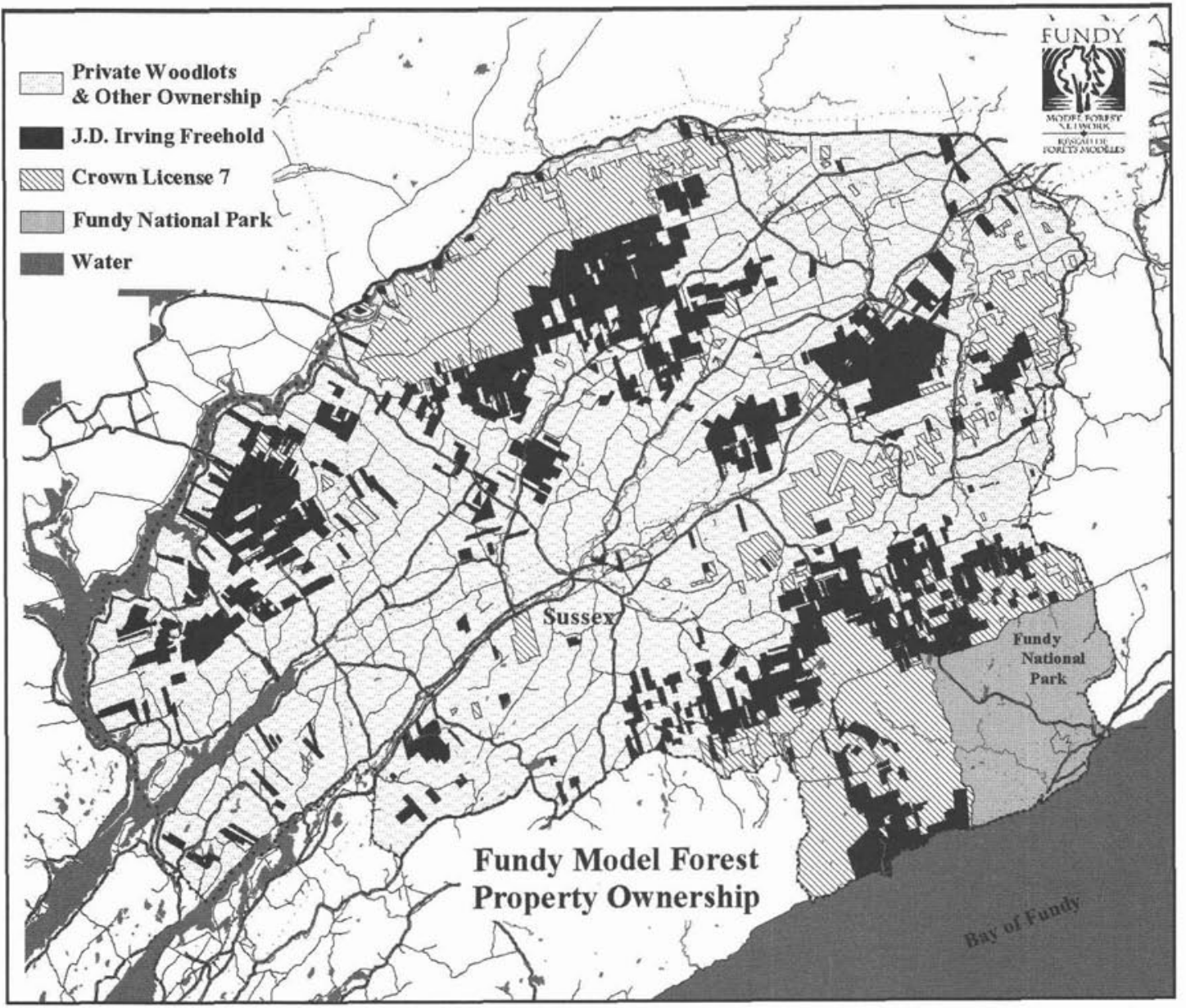

Fig. 2. Land ownership of the Fundy Model Forest is comprised of 265000 ha of private woodlots, 63000 ha Crown land, 71000 ha J.D. Irving, Limited industrial freehold, and 21000 ha Fundy National Park.

strategy in attaining the established objectives is then evaluated.

Of the four original objectives of the FMF, two related directly to the development of a sustainable forest management planning process:

The Planning System - To develop a system for integrated forest landscape management that addresses ecosystem dynamics, multiple ownership and public interest.

The Plan - To design and implement a plan for sustainable forest landscape management; subsequently, this was modified to a case study, designed to develop the process.

Forestry Practices - To design, implement and assess forest management practices that will result in better ecosystem management.

Research - To develop and implement a research strategy to support sound ecosystem management.

The FMF Partnership decided to develop this sustainable management planning process through a case study approach, using "what if' scenario planning on a portion of the Model Forest (114000 ha out of the total area of 420000 ha) (Fig. 4). The intention was that a subset area be used to develop the methodology, and that the process then would be applied by each landowner to their own land base, with the FMF playing a role in facilitating joint implementation across ownerships. It was recognized that other ongoing work proceeding within FMF related to planning and implementation, particularly in terms of development of on-the-ground best management practices and Criteria and Indicators of sustainable development (implementation of a modified set of Canadian Council of Forest Ministers (1995) Criteria and Indicators) (Fig. 4). The case study area was used to do scenario planning analyses based upon the public and Partnership input into values and practices, and modeling of projected effects. Based upon the Partnership's acceptance of this process, management strategies are now being developed for the whole FMF area.

\section{What is scenario planning?}

One of the best methods for conveying the consequences of alternative management actions or natural disturbance regimes is scenario planning (MacLean 1998). Scenario planning is a disciplined method for imagining possible futures that has been applied to a wide range of issues (Schoemaker 1995). Among the many tools a manager can use for strategic planning, scenario planning is unique for its ability to capture a whole range of possibilities and thereby to allow managers to see a wider range of possible futures (Schoemaker 1995). This is particularly effective in evaluating public concerns or issues related to forest management plan preparation. It also helps members of the public to participate in planning processes and to objectively evaluate contentious issues such as clear- 
Table 1. Fundy Model Forest partners - Phase II 1997-2002.

Atlantic Society of Fish and Wildlife Biologists

Canadian Institute of Forestry, Maritime Section

Canadian Forest Service

City of Moncton

Conservation Council of New Brunswick

Environment Canada

Fawcett Lumber Company

Fundy Environmental Action Group

Fundy National Park

Fundy Wilderness Coalition Inc.

Greater Fundy Ecosystem Research Group

J.D. Irving, Limited

Maritime Forest Ranger School

New Brunswick Department of the Environment

New Brunswick Department of Natural Resources and Energy

New Brunswick Federation of Naturalists

New Brunswick Premier's Round Table on the Environment \& Economy

New Brunswick School District 4

New Brunswick School District 6

Nova Forest Alliance

Petitcodiac Sportsman's Club

Southern New Brunswick Wood Cooperative Limited

Sussex Chamber of Commerce

Sussex Fish and Game Association

Sussex Town Council

Université de Moncton

University of New Brunswick - Faculty of Forestry

University of New Brunswick - Saint John Campus

Village of Petitcodiac

Washademoak Environmentalists

cutting, establishment of conservation areas, sustainability, and wildlife habitat preservation. A scenario planning approach often includes a series of workshops involving land managers, interests groups, stakeholders, and the public that:

1) elicits public and interest group issues or concerns;

2) formulates these issues into a series of scenarios to be evaluated for the land base in question;

3) conducts scenario analysis using forest development and timber supply models;

4) evaluates scenarios;

5) by consensus, reaches a single or small number of preferred scenarios; and

6) conveys these preferred management scenarios to land managers for implementation.

This was the approach used by the FMF.

\section{Case Study Area Description}

The case study area used for analysis consisted of several watersheds comprising 114000 ha in the eastern FMF. About 71\% of the area was available for timber harvest, while $29 \%$ was reserved for non-timber priority areas (in which some cutting may be allowed). Mapped non-timber priority areas included Fundy National Park, conservation areas, deeryards, mature coniferous forest wildlife habitat, protected (rare or unique, gap analysis) sites, steep (>20\%) slope areas, inoperable areas, riparian buffers, and suggested wildlife travel corridors. Land ownership was $47 \%$ small private woodlots, $24 \%$ Crown land, $20 \%$ J.D. Irving, Limited freehold, and 9\% Fundy National Park.

The area had been classified into four ecological districts (based on the NB Site Classification System) and 13 forest community types: 1) Eastern Lowlands ecodistrict - cedar, conifer, mixedwood; 2) Continental Lowlands ecodistrict - conifer, jack/red pine, white pine, tolerant hardwood, mixedwood; 3) Southern Uplands ecodistrict - conifer, mixedwood, tolerant hardwood; and 4) Fundy Coastal ecodistrict - conifer, mixedwood. Although assigned generic names, each community type within an ecodistrict represented a particular species composition. Stand development patterns, volume yields, natural succession, and treatment response were constructed for each community type.

\section{The FMF Planning Process}

There are seven general steps (Gardner Pinfold 1996) in the FMF sustainable forest management planning process, as follows:

\begin{tabular}{|c|c|}
\hline Step & Purpose \\
\hline 1. Identify & Basis for setting objectives \\
\hline ctics & Defin \\
\hline $\begin{array}{l}\text { 3. Assemble information } \\
\text { and management tools }\end{array}$ & Forecasts of forest change \\
\hline 4. Analysis of strategies & $\begin{array}{l}\text { Explore options, outcomes, } \\
\text { tradeoffs }\end{array}$ \\
\hline 5. Dec & Select strategy to implemen \\
\hline 6. Implement on the gr & Talk becomes action \\
\hline 7. Monitor/evaluate & Forest effects as expected? \\
\hline
\end{tabular}

We will discuss the status and future plans for each of these steps in the following sections. In summary, however, steps one to four were initially completed for the case study area of the FMF, and then were implemented by each landowner for their own land base. Step five is in progress and is associated with the development of Local Level Indicators of sustainability. The planning process has therefore been extended to the full Model Forest and beyond as landowners apply it to their land bases which extend outside the FMF. It will integrate the multi-ownership decision-making process, and link best management practices and the monitoring and evaluation process (Indicators) to the planning strategy.

\section{Identify Forest Values}

The definition of forest management objectives is based on values. Effects of a strategy on a value must be identifiable in a forecast of forest development over time.

Three types of values were identified in the FMF. Biodiversity and ecological integrity measures, as defined by Greater Fundy Ecosystem Research Group (Woodley and Forbes 1997), included abundance of ecological forest communities by age class, area of community harvested according to its natural disturbance pattern (emulating stand replacement versus gap replacement), maintenance of a network of protected areas and connectivity corridors, and protection of forest along streams by restricting harvesting techniques in streamside buffers. The second value was timber supply, the volume harvested by species and product. The third type of value was maintenance of wildlife habitat; specifically, management of deer wintering areas to maintain forest cover and the maintenance of mature coniferous forest habitat with particular structural specifications (Woodley and Forbes 1997). Recreation values were also considered.

\section{Identify Treatment Tactics}

This step specifically defined the ways by which each class of forest stands can be harvested, tended, and protected. 


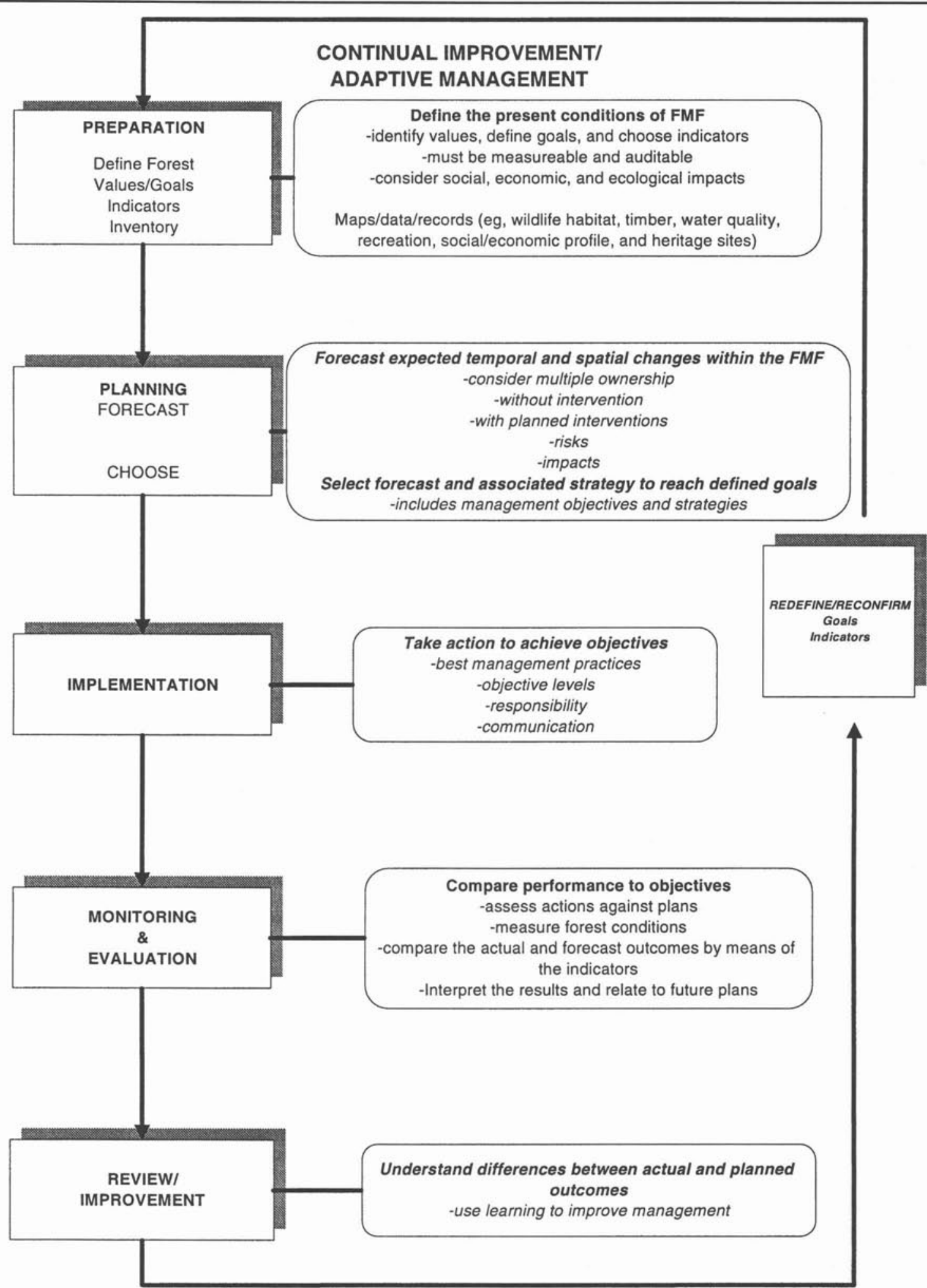

Fig. 3. Description of the Fundy Model Forest sustainable forest management planning loop.

Effects of each treatment on development of all eligible ecological communities were determined.

The FMF treatment set included six harvesting treatments (selection, shelterwood, clearcut, modified clearcut (2-pass), commercial thinning, and multiple entry in buffers), six silviculture treatments (planting with herbicide use, planting with no competition control, tree improvement, precommercial spacing of softwood, mixedwood, or hardwood stands), and two 


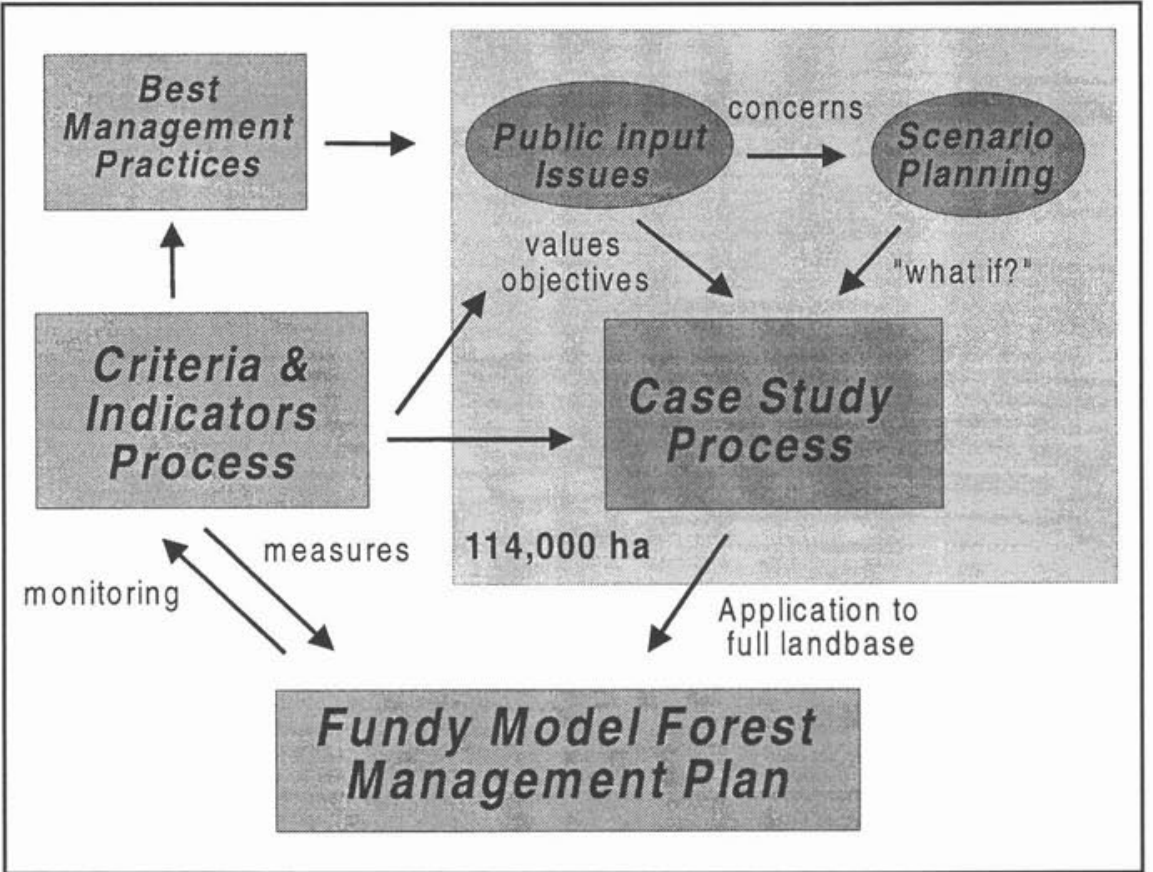

Fig. 4. A case study on a 114000 -ha area (about one-quarter of the FMF land base) was used to develop a management planning process. Links were developed with other FMF projects to develop best management practices and Criteria and Indicators of sustainable management. protection options (B.t. spraying against spruce budworm during outbreak periods versus no protection). Every community type was assigned eligible treatments based on its ecological relationships.

\section{Assemble Information and Management Tools}

Information and management tools are needed to explore alternative strategies and the effectiveness in achieving forest value objectives. A detailed biophysical inventory was constructed: forest cover type maps, ecoregion (site) maps, new forest inventory plots, locations of protected site candidates. Then forest stands were stratified into ecodistrict-based forest communities. Stand development patterns, volume yields, natural succession patterns, and treatment responses were constructed based on the best available data for each relevant community type/ treatment combination. Data were input to an ARC/INFO GIS, and geographic zones for treatment eligibility were defined (e.g., buffers for $5 \mathrm{~m}$ no harvest, $60 \mathrm{~m}$ modified harvest, park buffers, protected areas, $300 \mathrm{~m}$ wide connectivity corridors).

\section{Analysis of Alternative Strategies}

In this step, the various management strategies and tactics were examined with respect to their forecast effects on forest values. Public consultation and Partnership input were used to define issues and scenarios of interest. The Woodstock forest modeling system (Remsoft Inc. 1996) was used to conduct aspatial projections of the case study area for 80 years for each scenario. Indicators examined included changes in harvested volumes (total, spruce-fir-pine, hardwood), area eligible for harvest, area by forest community type, mature area by community type, and areas harvested, thinned, or planted.

Development of the FMF planning process began by identifying issues of concern to the Partnership organizations in a workshop in January 1996. This was followed by a public consultation process, which identified nine major issues of con- cern to the general public. In a May 1996 workshop, the issues derived from both sources were discussed, quantified and refined into six groups of issues, and a total of 25 scenarios were defined for analysis. Database preparation was largely complete by this time, and aspatial analyses of scenarios began. In a second workshop in October 1996, the Partnership reviewed the results of scenarios, and discussed implications to forest structure, biodiversity, and timber production. Following two days of discussions, the Partnership by consensus defined a "preferred" FMF management scenario (Table 2). In November 1996, this preferred scenario was conveyed to the four landowner organizations for their consideration and additional model runs, including spatial analyses for some scenarios, were begun. In a third workshop in April 1997, the landowners responded to the Partnership. In most cases, the landowners agreed to implement the FMF preferred scenario, or agreed in principle with the intent, with some specifics still to be worked out.

Results for 18 of the scenarios are presented in Table 3. The base case (status quo, or current management practices) scenario predicted non-declining, long-run sustained timber yields of $1059000 \mathrm{~m}^{3}$ (per five-year period) total harvest for the next 80 years, with $554000 \mathrm{~m}^{3} /$ period of softwood and $475000 \mathrm{~m}^{3} /$ period of hardwood species (Table 3 ). All other scenarios were compared with this standard. Scenarios generally varied one factor (e.g., harvesting in water buffers) at a time, in order to evaluate relative impacts, and then several combined scenarios were run. Table 3 presents a summary description of each scenario and the percentage change in harvest volume that resulted. In evaluating scenarios, additional indicators examined included the total area and mature forest area of each of the 13 ecological community types, the harvested area, sustainable timber production, the area of plantations, and the maintenance of conservation areas.

Many of the scenarios alone resulted in sustained timber yield reductions of $1-6 \%$ (Table 3 ). The combined biodiversity scenario (no. 8a), incorporating elements related to water buffers, 
Table 2. The "preferred" Fundy Model Forest management planning scenario, agreed to by consensus by 30 Partnership organizations. This was the Partnership's recommended management regime, arising from consideration of $\mathbf{2 5}$ scenarios.

Water buffers

30-m riparian buffer with partial harvest only; 5-m noncut buffer to be implemented via Best Management Practice (BMP); no harvest on slopes $>20 \%$; buffer to begin where slope becomes $<20 \%$

Road construction Provincial guideline of 30-m partial harvest only buffer along numbered highways; careful road construction via BMPs

Vegetation and insect control

Harvesting

Populations of plant/ animal species
Use of biological insecticide B.t. acceptable during spruce budworm outbreaks; consensus on acceptability of vegetation control, but NOT on method - recommended the use of the most feasible, environmentally sensitive method, only for clearcut/plant treatments

Use harvest to emulate natural disturbance pattern (gap versus stand replacement - Woodley and Forbes 1997); further work required for several communities that were not clearly gap or stand replacing

Accepted the need for connectivity corridors (with provisos of limitations of

establishment on private woodlots, and not necessarily as currently mapped); protection of rare/unique (gap analysis) sites and maintenance of $12 \%$ of pre-settlement condition community types in mature condition (spatial aspects to be analyzed); $0.5-1.0 \mathrm{~km}$ Park buffers rejected (landowners should work together to protect Park integrity)

Plantations

No new use of exotic species in planting program; maximum of $5 \%$ of area, by ecodistrict, for Norway spruce planting; no final agreement on planting scenario (two options retained: planting acceptable where softwood regeneration stocking $<40 \%$ versus areas unstocked to any commercial species)

Table 3. Results of scenario planning analyses for a 114000 ha portion of the Fundy Model Forest. Effects of scenarios on changes in harvested volumes (\%), in comparison with the base case (status quo) scenario (no. 1), are presented.

\begin{tabular}{|c|c|c|c|}
\hline \multirow[b]{2}{*}{ Scenario } & \\
\hline & Total & Spruce-fir-pine & Hardwood \\
\hline 1 - Base case (harvest $\mathrm{m}^{3} /$ five-yr period) & 1059000 & 554000 & 475000 \\
\hline 2a - Water buffers: $5 \mathrm{~m}$ no cut, $60 \mathrm{~m}$ select cut only, start buffer where slope $<20 \%$ & -8 & -8 & -6 \\
\hline $2 \mathrm{~b}$ - Water buffers: $60 \mathrm{~m}$ no cutting & -13 & -13 & -9 \\
\hline $3 \mathrm{a}$ - Road buffers: $60 \mathrm{~m}$ no cutting & 0 & 0 & 0 \\
\hline 4f - No herbicide use & -4 & -9 & +6 \\
\hline 4h - Manual vegetation control & -1 & -1 & -1 \\
\hline 5a - Maintain $300 \mathrm{~m}$ wide mature forest corridors to connect forest areas & -3 & -3 & -2 \\
\hline $5 \mathrm{~b}$ - Preserve rare/unique (gap analysis) sites & -2 & -2 & -1 \\
\hline $5 \mathrm{c}$ - Maintain $12 \%$ of each ecological. community type in mature/overmature age class & 0 & 0 & -1 \\
\hline $5 \mathrm{~d} 1-1.0 \mathrm{~km}$ buffer around Parks (select cut only) & -4 & -5 & 0 \\
\hline $5 \mathrm{~d} 2-0.5 \mathrm{~km}$ buffer around Parks (select cut only) & -2 & -3 & 0 \\
\hline 6a - Harvest guidelines (partial cutting only in gap-replacing community types) & -21 & -21 & -21 \\
\hline \multicolumn{4}{|l|}{$6 \mathrm{~b}$ - Harvest guidelines (clearcutting allowed in community types that can be either gap } \\
\hline or stand replacing) & -6 & -6 & -5 \\
\hline 7a - Harvest guidelines (6a), plant only unstocked areas & -22 & -24 & -15 \\
\hline $7 \mathrm{~b}$ - Harvest guidelines (6a), no planting & -23 & -26 & -7 \\
\hline $7 \mathrm{c}$ - Harvest guidelines (6a), plant all areas with softwood regeneration $<60 \%$ & +5 & +8 & -22 \\
\hline $7 \mathrm{e}$ - Base case scenario (1), no planting & -5 & -11 & +8 \\
\hline $8 a-$ Combined biodiversity preservation scenario $(2 a+5 a+5 b+5 c+6 a)$ & -28 & -28 & -24 \\
\hline
\end{tabular}

Note: More information about the guidelines for the biodiversity-related scenarios (Nos. 2a, 5a, 5b, 5c, 6a, 8a) is provided in Woodley and Forbes (1997).

connectivity corridors, preservation of rare/unique sites, maintenance of $12 \%$ of each community type in mature forest, and using harvesting to emulate natural disturbance, resulted in a cumulative $28 \%$ reduction in timber volume yield. However, $21 \%$ of this reduction resulted from effects of harvest guidelines (specifying partial cutting only in gap-replacing community types) (Table 3 ). This was determined to be an important area that required further research to reduce uncertainty.

When examining effects on maintenance of mature area of each community type, results varied considerably. In some stand types, certain scenarios resulted in not meeting the target $12 \%$ of pre-settlement forest in mature stand condition. In other cases, all scenarios would easily meet the mature forest targets, but in a few community types, restoration will be required to attain target areas of mature forest.

\section{Decision-Making}

Decision-making is the step in which a strategy that best meets the forest management objectives is selected. The FMF Partnership is not a landowner and has no management authority, so is not directly involved in decision making. However, for the Model Forest process to be of real value, there must be actual change in how the landowners manage. One way for this to occur is to have the landowners endorse the planning process and apply it to their own holdings (Gardner Pinfold 1996). There are two facets to this: 1) immediate adoption and implementation of partnership-endorsed operational best management practices (e.g., rules for snag retention or coarse woody debris management); and 2) application of the FMF planning process in management plan formulation by each landowner. This has indeed occurred, with the Southern New Brunswick Wood Cooperative Ltd. (SNB), J.D. Irving, Limited 


\begin{tabular}{|c|c|}
\hline October 1997 & Finalized set of Local Level Indicators for the FMF \\
\hline November 1997 & Landowner evaluation of FMF Indicator Set \\
\hline December 1997 & Landowner presentations on selected Indicators \\
\hline May 1998 & Finalized landowner Indicator Set and management strategies \\
\hline November 1998 & Southern New Brunswick Wood Cooperative (SNB) management plan completed for the total private woodlot land base \\
\hline December 1998 & J.D. Irving, Limited (JDI) management plan completed for the industrial freehold land base \\
\hline March 1999 & Landowner presentations of management plans to the FMF Partnership \\
\hline Mid 1999-2000 & $\begin{array}{l}\text { Integration of landowner (JDI freehold and SNB) plans. Facilitation by the Fundy Model Forest as a test case of the integration } \\
\text { process (aspatial integration). }\end{array}$ \\
\hline Late 1999 & Refinement of management plans by landowners \\
\hline January 2000 & $\begin{array}{l}\text { Crown land objectives set. The objectives for the } 2002 \text { plan will be finalized by this date to ensure completion of the Crown } \\
\text { License } 7 \text { plan by } 2001\end{array}$ \\
\hline 2000 & Begin final integration of Landowner's plans (JDI freehold, Crown License 7, SNB, and Fundy National Park) \\
\hline 2001 & Crown plan finalized - JDI will have completed a management plan for Crown License 7 \\
\hline 2002 & Integrated FMF management plan for the combined SNB + Crown License $7+$ JDI freehold land base + Fundy National Park \\
\hline 1997-2000 & Research and database activities to reduce uncertainty in the planning process \\
\hline 1997-2001 & $\begin{array}{l}\text { Design and implementation of Monitoring and Evaluation Process } \\
\text { Formulate ways to compare planned versus actual activities } \\
\text { Periodic reporting of results to Partnership } \\
\text { Scientific evaluation component, to test key assumptions and data sets used in management plan formulation } \\
\text { Further linkage with FMF C\&I process }\end{array}$ \\
\hline
\end{tabular}

(JDI), and Fundy National Park using consistent databases and methodology to conduct analyses for their actual management land bases, both inside and outside of the FMF. This has resulted in the FMF planning process being applied to an area over three times the size of the FMF.

There should be a full accounting by landowners to the Partnership of the strategies explored, trade-offs, and the rationale for their selected strategy (Gardner Pinfold 1996). Although the owner's strategy may differ from the Partnership's, it likely will be more acceptable to all parties because it has input of the partners. Ideally, the FMF planning process, or elements of it, will eventually be adopted and implemented as provincial government policy. Planning processes in NB are moving in this direction, with NB Department of Natural Resources and Energy (NB DNRE) and Crown Licensee efforts to develop a consistent set of volume yield curves for use on all Licenses, and exploration of basing these on ecological regions as in the FMF case study.

\section{Implement on the Ground}

Implementation is the step where managers carry out the selected strategy. The FMF process has not yet reached the implementation stage, although it is nearing it for the application of the SNB and JDI plans. One factor that comes into play here is the degree of management control (Gardner Pinfold 1996): J.D. Irving, Limited can implement new strategies readily on their own land base; the Crown forest already has an iterative, five-year management planning cycle (1997-2001), so that it is difficult to change procedures until the next iteration, beginning in 2002; the Southern New Brunswick Wood Cooperative organization includes up to 3500 separate owners, each with management control on their own land base, so encouragement, persuasion, and education of individual owners to get the desired strategy implemented is the necessary approach.

\section{Monitoring and Evaluation}

The last step is to determine if the chosen strategy is being implemented as planned and is having the desired effects. The FMF has not yet reached this stage, but implementation of Criteria and Indicators of sustainable development (Canadian Council of Forest Ministers 1995) is a key objective for the second phase (1997-2001) of the FMF. There should be periodic reporting to the Partnership on the status of indicators and reconciliation of planned versus actual monitored levels. It is key that indicators be projected into the future as part of management plan formulation, and that they be monitored. This requires that each indicator be functionally linked to forest structural characteristics. There also should be a scientific evaluation component to test and improve assumptions and data, and thereby reduce uncertainty in future planning iterations via adaptive management.

\section{Where do we go from here?}

The management planning activities in Phase II (1997-2001) of the FMF is focusing on the integration of sustainable forest management plans for all landowners across the entire FMF land base. Thus, indicators of forest composition (vegetative community by ecodistrict), maturity, and productivity are determined for the aggregate SNB + JDI + Crown License 7 + Fundy National Park land base. A time line for activities is presented in Table 4. The Partnership may exercise the option to include more forest values in the FMF planning process than the landowners have included in their plans; this would require FMF staff to conduct additional analyses of future conditions.

A second major objective in FMF Phase II is to address and develop a functional, local set of indicators of sustainable management. This has a direct impact on the management planning activities. It is largely scenario planning and forecasting of the indicators over time that enables landowners to evaluate and implement a local indicator set. Through the indica- 
tors process, the FMF Partnership will have direct input into the value set and objective levels incorporated into landowner management plans.

\section{Conclusions}

Multiple land ownerships is a key strength (and difficulty) of the FMF sustainable forest management area. Using scenario planning, a case study process built a management scenario for a 114000 -ha land base, which met the consensus approval of the 30-organization Partnership. The focus was on developing a process for setting of and managing for objectives, including biodiversity. Key progress has been made in modeling the forest (vegetative community type by ecodistrict); in using forecasting models to control treatment levels in a way that satisfies objectives for a broad range of forest values; and in incorporating biodiversity guidelines (Woodley and Forbes 1997) into forest management. Implementation of the common sustainable forest management planning process is underway by FMF landowners. Tasks remaining are to integrate plans across ownerships and to more closely link planning indicators to the FMF local-level Criteria and Indicators of sustainable management (Canadian Council of Forest Ministers 1995). These are key objectives of the Fundy Model Forest Phase II (1997-2001).

\section{Acknowledgements}

Development of the Fundy Model Forest management planning process came about because of the input of many people. Dr. Graham Forbes, Dan Beaudette, and other members of the FMF Management Planning Technical Committee made major contributions. Many representatives of the $30 \mathrm{FMF}$
Partnership organizations provided input and feedback in a series of workshops; without their input, the process could not have worked. Dr. Thom Erdle and Gardner Pinfold Consulting Economists Ltd. provided thoughtful analyses of the planning process at the end of FMF Phase I. David Young of J.D. Irving Limited and Brian Belyea of SNB Woodlot Owners Cooperative have led implementation on their respective land bases.

\section{References}

Brand, D.G., O.T. Bouman, L. Bouthillier, W. Kessler, and L. LaPierre. 1996. The Model Forest concept: a model for future forest management? Environmental Review 4: 65-90.

Canadian Council of Forest Ministers. 1995. Defining sustainable forest management: a Canadian approach to Criteria and Indicators. Natural Resources Canada, Ottawa, Canada. 22 p.

Gardner Pinfold Consulting Economists Ltd. 1996. An evaluation of the Fundy Model Forest. Report prepared for the Fundy Model Forest, Sussex, NB. 25p. + appendices.

MacLean, D.A. 1998. Landscape management for restructuring forest areas. In G.J. Nabuurs, T. Nuutinen, H. Bartelink, and M. Korhonen (eds.). Forest Scenario Modelling for Ecosystem Management at Landscape Level, June 24-July 4, 1997, Wageningen, The Netherlands. pp. 25-45. European Forest Inst., Joensuu, Finland. Proc. No. 19. Remsoft, Inc. 1996. Woodstock Forest Modelling System Version 1.1 user's guide. Remsoft Inc., Fredericton, New Brunswick, Canada. $125 \mathrm{p}$.

Schoemaker, P.J.H. 1995. Scenario planning: a tool for strategic thinking. Sloan Management Review, Winter 1995: 25-40.

Woodley, S. and G. Forbes (eds.). 1997. Forest management guidelines to protect native biodiversity in the Fundy Model Forest. Greater Fundy Ecosystem Research Group, University of New Brunswick, Fredericton, New Brunswick, Canada. 